\title{
Pengembangan Kapasitas Kelembagaan Lokal dan Tingkat Realisasi Program Penataan Lingkungan Permukiman di Perkotaan
}

\author{
Anggun Aprinasari Fultanegara ${ }^{1}$
}

Diterima : 20 Juni 2014

Disetujui : 4 Juli 2014

\begin{abstract}
Problem of slum area is a much appear in cities. It demands people to settle the problem independently, one is local institutional. This research tries to compare seven BKM, namely four BKM in Kendal and three BKM in Pekalongan. The implementation of the PLPBK program is measured from the BLM funds utilization, realization of program utilization BLM, and the amount of partnership program. Later, local institutional capacity was measured with a three-level, namely the level of individuals, groups, and organizations. Research carried out using quantitative methods, descriptive, scoring analysis, and collecting data kuisioner. Results of analysis showed the seventh BKM have done well. Nevertheless, Kebondalem Region in Kendal is the best. Furthermore, the results of the analysis indicate the capacity in seven BKM get in on class II which is good in running the PLPBK program. However, BKM which has the highest score is Kramatsari Region in Pekalongan city with a score of 4.5.
\end{abstract}

Keywords: local institutional, institutional capacity, implementation program, Community-Based Neighbourhood Development

\begin{abstract}
ABSTRAK
Permasalahan lingkungan permukiman kumuh merupakan fenomena yang banyak muncul di perkotaan. Hal tersebut menuntut masyarakat untuk menyelesaikan permasalahan tersebut secara mandiri, salah satunya adalah kelembagaan lokal. Tujuan dari penelitian ini adalah mengkaji kapasitas kelembagaan lokal dan tingkat realisasi program PLPBK dengan mengkomparasikan tujuh BKM, yaitu empat BKM di Kabupaten Kendal dan tiga BKM di Kota Pekalongan. Tingkat realisasi program PLPBK diukur dari realisasi pemanfaatan dana BLM, program pemanfaatan dana BLM, dan besaran kemitraan program. Kemudian, kapasitas kelembagaan lokal diukur dari level individu, kelompok, dan organisasi. Penelitian dilakukan dengan menggunakan metode kuantitatif deskriptif serta teknik analisis skoring dan pengumpulan data kuisioner. Hasil analisis menunjukkan ketujuh BKM telah melaksanakan program PLPBK dengan baik. Namun demikian, Kelurahan Kebondalem Kabupaten Kendal paling baik dibandingkan lainnya. Selanjutnya, dari hasil analisis skoring menunjukkan kapasitas di tujuh BKM masuk pada kelas II yaitu baik dalam menjalankan program PLPBK. Namun, BKM yang memiliki skor yang paling tinggi adalah BKM di Kelurahan Kramatsari Kota Pekalongan dengan skor 4,5.
\end{abstract}

Kata kunci: kelembagaan lokal, kapasitas kelembagaan, realisasi program, PLPBK (Penataan Lingkungan Permukiman Berbasis Komunitas)

\footnotetext{
${ }^{1}$ Mahasiswa Magister Pembangunan Wilayah dan Kota, Undip, Semarang, Jawa Tengah Kontak Penulis: anggun_fultanegara@yahoo.com
} 


\section{PENDAHULUAN}

Permasalahan lingkungan permukiman kumuh merupakan fenomena yang banyak muncul di perkotaan. Permasalahan ini menjadi krusial disaat semakin banyaknya permukiman kumuh dengan minimnya solusi yang implementatif. Hal tersebut menuntut masyarakat untuk dapat menyelesaikan permasalahan lingkungan permukimannya secara mandiri. Salah satu lembaga yang berpotensi dalam menyelesaikan permasalahan ini adalah kelembagaan lokal. Kelembagaan lokal itu sendiri dengan adanya aturan-aturan (rules) dan peran-peran (roles) yang melaksanakan tindakan kolektif untuk pencapaian tujuan dan penyelesaian permasalahan (Mehring et al, 2011). Peran kelembagaan lokal dalam hal ini cukup besar sebab merupakan salah satu aktor penting dalam menyelesaikan permasalahan lingkungan kumuh dan penataan kawasan permukiman disaat pemerintah memiliki keterbatasan.

Salah satu program pemerintah penataan lingkungan permukiman di perkotaan yang berbasis kesejahteraan masyarakat, yakni program Penataan Lingkungan Permukiman Berbasis Komunitas (PLPBK). Program PLPBK telah berjalan sejak tahun 2008 di Indonesia dan salah satu wilayah sasarannya adalah Provinsi Jawa Tengah. Melalui program ini dengan menjadikan masyarakat sebagai subjek pembangunan melalui pemberdayaan masyarakat. Harapannya, masyarakat memiliki kapasitas dalam memetakan potensi yang ada, merencanakan, dan menata lingkungannya secara mandiri.

Kelembagaan dalam program ini cukup bervariasi. Kinerja BKM yang ada di Kabupaten Kendal dan Kota Pekalongan yang bervariatif dipengaruhi oleh beberapa faktor, antara lain pemanfaatan dana BLM yang masing-masing BKM memiliki kapasitas dalam penyerapan dana yang berbeda-beda, kinerja dalam implementasi terhadap permasalahan penataan lingkungan, dan keterbatasan kapasitas kelembagaan lokal (Satker PBL Provinsi Jawa Tengah).

Peningkatan kinerja program PLPBK dalam upaya dan penataan lingkungan permukiman kumuh salah satunya dilakukan dengan pengembangan kelembagaan lokal. Kelembagaan lokal pada penelitian ini berupa Badan Keswadayaan Masyarakat (BKM) sebagai lembaga nirlaba yang bersifat nonstruktural pada wilayah/ daerah tertentu yang melakukan kegiatan secara kolektif melalui penetapan tujuan dan pelaksanaan kegiatan bersama (Mehring et al, 2011).

Data hasil monitoring dan evaluasi Satker PBL Provinsi Jawa Tengah (2012) menggambarkan bahwa dari 185 kelurahan yang melaksanakan PLPBK, hanya sebagian kecil saja yang dikatakan berhasil pada pemanfaatan program (outcomes), sebagian besar hanya pada tahap implementasi program (output) dan bahkan ada yang gagal atau tidak mampu menjalankan kegiatan sampai selesai. Hal ini menandakan tidak semua BKM telah siap dan memiliki kapasitas dalam perwujudan program PLPBK secara efektif. Selain itu, minimnya kemampuan serta menurunnya jiwa kerelawanan dalam merencanakan dan mengimplementasikan kegiatan PLPBK secara mandiri, efektif, dan berkelanjutan (TNP2K dalam Depkominfo, 2011).

Tujuan yang ingin dicapai dari penelitian ini adalah mengkaji kapasitas kelembagaan lokal dan tingkat realisasi program PLPBK. Pada penelitian ini, kajian tersebut dilakukan dengan komparasi tujuh BKM, yakni empat BKM di Kabupaten Kendal dan tiga BKM di Kota Pekalongan. Ketujuh lokasi tersebut dinilai baik dalam menjalankan program serta dua diantaranya merupakan lokasi pilot project dari program PLPBK di Jawa Tengah. Pertimbangan ketujuh lokasi tersebut diambil sebagai lokasi studi dengan berdasarkan penelitian terdahulu (Fultanegara, 2013), antara lain: hasil wawancara terstruktur Satker PBL Provinsi Jawa Tengah bahwa Kabupaten Kendal dan Kota Pekalongan menjadi duta PLPBK yang dinilai baik dalam 
menjalankan kegiatan PLPBK dan dari 185 desa/kelurahan di Provinsi Jawa Tengah, Kelurahan Kebondalem, desa Plantaran, Kutoharjo, dan Sidorejo di Kabupaten Kendal serta Kelurahan Podosugih, Kramatsari, dan Kraton Kidul di Kota Pekalongan telah mampu menyerap dana Bantuan Langsung Masyarakat (BLM) hampir 100\%.

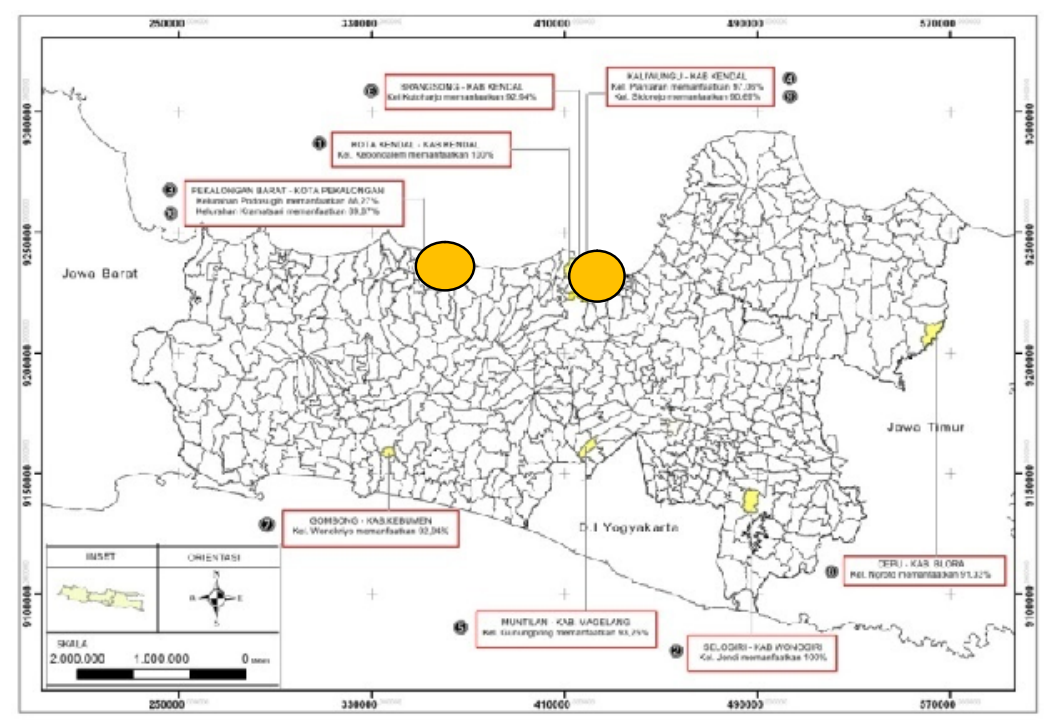

Sumber: diolah dari data Satker PBL Provinsi Jawa Tengah, 2012

GAMBAR 1

LOKASI PENELITIAN DI KABUPATEN KENDAL DAN KOTA PEKALONGAN

\section{METODE PENELITIAN}

Metode penelitian yang digunakan pada penelitian ini adalah kuantitatif. Dimana adanya variabel-variabel sebagai objek penelitian serta pengolahan data melalui deskriptif. Teknik sampling yang digunakan pada penelitian ini, yaitu purposive sampling atau sampel terpilih, dengan beberapa pertimbangan seperti sampel wilayah yang diambil dapat merepesentatifkan BKM yang sukses menjalankan PLPBK, waktu, sumberdaya, dana yang terbatas, serta kemudahan dalam pengambilan data. Responden yang menjadi sampel pada penelitian ini adalah anggota yang terlibat langsung dalam program PLPBK di kelurahan/desanya. Diketahui jumlah populasi dari tujuh BKM yang ada di Kabupaten Kendal dan Kota Pekalongan, yakni tiap BKM sebesar 15 orang. Untuk memudahkan pengambilan data serta merepresentasikan sampel dalam keseluruhan populasi secara merata, diambil sebesar 10 sampel tiap BKM. Pembagian sampel pada tujuh kelurahan di Kabupaten Kendal dan Kota Pekalongan sebagai berikut:

TABEL 1

PEMBAGIAN SAMPEL

\begin{tabular}{llll}
\hline No & Nama BKM & Desa/ Kelurahan & $\begin{array}{l}\text { Jumlah Anggota } \\
\text { (orang) }\end{array}$ \\
\hline Kabupaten Kendal & & \\
\hline 1. & BKM Sejahtera Mandiri & Kebondalem & 10 \\
\hline 2. & BKM Sumber Makmur & Sidorejo & 10 \\
\hline 3. & BKM Mulia & Kutoharjo & 10 \\
\hline
\end{tabular}




\begin{tabular}{llll}
\hline No & Nama BKM & Desa/ Kelurahan & $\begin{array}{l}\text { Jumlah Anggota } \\
\text { (orang) }\end{array}$ \\
\hline 4. & BKM Mekar Sari & Plantaran & 10 \\
\hline Kota Pekalongan & & \\
\hline $5 . \quad$ BKM Podosugih & Podosugih & 10 \\
\hline $6 . \quad$ BKM Barokah & Kramatsari & 10 \\
\hline 7. & BKM Aji Rasa & Kraton Kidul & 10 \\
\hline \multicolumn{2}{l}{ Total } & & 70 \\
\hline \multicolumn{2}{l}{ Sumber: Analisis Penyusun, 2014}
\end{tabular}

Teknik analisis yang digunakan dalam penelitian ini adalah statistik deskriptif dan skoring dengan Likert Scale. Untuk analisis statistik deskriptif digunakan untuk menganalisis karakteristik individu dan tingkat realisasi program serta analisis skoring dengan Likert Scale untuk menganalisis kapasitas kelembagaan lokal. Untuk perhitungan skor dari masing-masing responden, penggunaan skala ini diperoleh dengan lima alternatif jawaban yang berjenjang (ordinal), seperti sangat baik, baik, kurang baik, dan tidak baik. Berikut ini adalah kelas hasil skoring:

TABEL 2

KELAS HASIL SKORING

\begin{tabular}{lll}
\hline Kelas & Keterangan & Skor \\
\hline I & $\begin{array}{l}\text { Kapasitas BKM sangat baik dalam } \\
\text { menjalankan kegiatan PLP-BK }\end{array}$ & 5 \\
\hline II & $\begin{array}{l}\text { Kapasitas BKM baik dalam } \\
\text { menjalankan kegiatan PLP-BK }\end{array}$ & 4 \\
\hline III & $\begin{array}{l}\text { Kapasitas BKM biasa saja dalam } \\
\text { menjalankan kegiatan PLP-BK }\end{array}$ & 3 \\
\hline IV & $\begin{array}{l}\text { Kapasitas BKM tidak baik dalam } \\
\text { menjalankan kegiatan PLP-BK }\end{array}$ & 2 \\
\hline V & $\begin{array}{l}\text { Kapasitas BKM sangat tidak baik } \\
\text { dalam menjalankan kegiatan PLP-BK }\end{array}$ & 1 \\
\hline Sumber: & Analisis Penyusun, 2014
\end{tabular}

\section{KAJIAN TEORI}

\section{Kapasitas Kelembagaan}

UNDP (1998) dalam Bossert dan Mitchel (2010) mengungkapkan bahwa kapasitas sebagai suatu kemampuan individu, organisasi atau sistem dalam menjalankan fungsinya secara efektif, efisien, dan berkelanjutan. Kelembagaan (institutional) terdiri dari dua aspek, yakni aspek kelembagaan yang berisi nilai, visi, misi, tujuan, sistem serta aspek organisasai yang berisi peran, fungsi, struktur Boffin (2002) dalam Bossert dan Mitchel (2010). Hal ini juga sejalan dengan pemahaman Manaf (2012) yang mengungkapkan bahwa aspek kelembagaan dibagi menjadi dua, yakni aspek pranata (rule oriented approach) dan organisasi (role oriented approach).

\section{Kelembagaan Lokal}

Lembaga lokal merupakan lembaga atau asosiasi yang berada pada tingkat lokal (wilayah/ daerah tinggal) yang secara bersama-sama proaktif terhadap kondisi yang ada melalui penetapan tujuan dan pelaksanaan kegiatan bersama (Mehring et al, 2011). Hal ini juga sejalan dengan yang diungkapkan oleh (Manaf, 2012) dimana lembaga lokal adalah lembaga yang berada pada tingkat dimana dilaksanakannya suatu tindakan kolektif atau usaha bersama 
dimana kepentingan, kebutuhan, potensi sumberdaya, dan idealitas dari sekelompok orang menjadi suatu tindakan bersama untuk mendapatkan kebaikan bersama.

\section{Pengembangan Kapasitas Kelembagaan Lokal}

Linneall dalam Kapucu (2011) mengungkapkan bahwa dalam pengembangan kapasitas kelembagaan dilakukannya suatu penambahan hal-hal baru yang bernilai baik sehingga adanya peningkatan kemampuan suatu lembaga dalam pencapaian misi. Pengembangan kapasitas kelembagaan lokal yang dimana pada penelitian ini adalah kapasitas BKM menggunakan pendekatan yang memfasilitasi tiap-tiap individu dan kemampuan masyarakatnya untuk menghadapi permasalahan serta mengambil keputusan. Berikut ini adalah model teoritis dari tingkatan kapasitas kelembagan lokal dari beberapa sumber literatur:

1. Level Individu

Pentingnya rasa kebersamaan dari tiap-tiap individu dapat mempengaruhi dari kehidupan sosial-masyarakatnya, seperti identitas dari masyarakat tersebut dan aturan- aturan yang tumbuh di masyarakat Hunter dan Suttles (1972) dalam Hughey et.al (1999: 97). Kapasitas kelembagaan pada level individu menurut McMillan dan Chavis (1896) dalam Hughey et.al (1999: 99-100) dapat dilihat dari seberapa anggota yang dikenal, seberapa sering interaksi yang terjadi, seberapa banyak pertemuan yang diikuti, dan seberapa lama waktu yang diluangkan untuk program PLPBK ini.

2. Level Kelompok

Level ini berupa kapasitas dari adanya peran-peran dan struktur atau fungsi yang diakui dan diterima serta hasil dari interaksi berbagai peran untuk mencapai suatu tujuan (Uphoff, 1986). Hal ini dapat diukur dari McMillan dan George (1986) dalam Sakip et.al (2012:820) tingkat kedekatan antar anggota/ keanggotan (membership), berupa tingkat kedekatan antar anggota, tingkat kepedulian (influence), berupa intensitas diskusi antar anggota dan alasan aktif mengikuti PLPBK, tingkat ketergantungan antar anggota (integration and fulfillment of needs), serta hubungan emosional (shared emotional connection), berupa interaksi antar anggota diluar program.

3. Level Organisasi

Pada level sistem kelembagaan ini berupa aturan yang menjadi dasar program, aktivitas, kebijakan, norma yang terdiri dari aspek kelembagaan dan aspek organisasi Boffin (2002) dalam Bossert dan Mitchel (2010). Hal ini diukur dari: tingkat kepemimpinan, tingkat kegotongroyongan, pemahaman tujuan, dan pembagian kerja.

\section{Badan Keswadayaan Masyarakat (BKM)}

BKM itu sendiri berdasarkan (Uphoff dalam Inam, 2002) merupakan lembaga nirlaba yang tujuannya melayani kepentingan masyarakat (anggota) secara bersama-sama. BKM bagian dari organisasi keanggotaan yang dimana sebagai asosiasi swadaya dengan tugas-tugas khusus. Badan Keswadayaan Masyarakat (BKM) ini juga yang terdiri dari tokoh-tokoh perwakilan yang berasaskan kepercayaan (trust) masyarakat di kelurahannya.

\section{Konsep Realisasi Program}

Konsep realisasi program merupakan bagian dari konsep efektivitas pelaksanaan program. Realisasi program itu sendiri (output) merupakan hal yang penting dalam mengukur kinerja program. Menurut Dunn (1998) untuk efektivitas terkait dengan pencapaian hasil (akibat) yang diharapkan atau pencapaian tujuan dari suatu tindakan. Tujuan utama dari efektivitas pelaksanaan program adalah untuk mengetahui perubahan yang ditimbulkan sebelum dan 
sesudah adanya program atau kegiatan, serta kinerja program mengenai seberapa jauh kebutuhan, nilai, dan kesempatan yang telah dicapai.

\section{Program PLPBK}

PLPBK yaitu program Penataan Lingkungan Permukiman Berbasis Komunitas yang pada dasarnya adalah program lanjutan dari P2KP (Program Penanggulangan Kemiskinan di Perkotaan) yang dibawah naungan Departemen Pekerjaan Umum sejak tahun 1999, yang sekarang disebut PNPM Mandiri Perkotaan (www.ciptakarya.pu.go.id). Melalui program PLPBK ini, masyarakat (kelompok sasaran program) didampingi untuk dapat menyusun rencana pengembangan dan penataan lingkungan tempat tinggalnya secara partisipatif.

Program ini dilalui dengan tiga jalur strategi (Pedoman Pelaksanaan PNPM Mandiri Perkotaan, 2009), antara lain:

1. Orientasi pada perubahan perilaku (attitude)

2. Orientasi pada pengelolaan oleh masyarakat sendiri (self community management)

3. Orientasi pada inovasi dan kreativitas masyarakat (enterpreneurship)

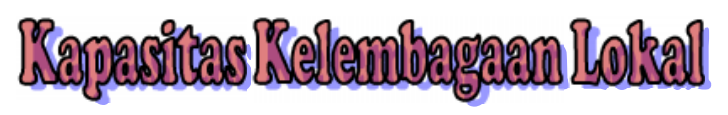

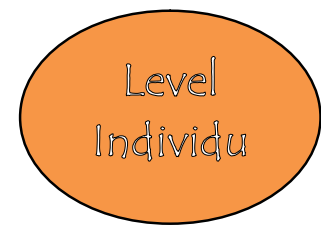

Karakteristik Individu

Dilihat dan dinilai berdasarkan pertanyaan kuesioner:

$\checkmark$ Usia

$\checkmark$ Status menikah

$\checkmark$ Lama tinggal

$\checkmark$ Asal penduduk

$\checkmark$ Jenis pekerjaan

$\checkmark$ Tingkat pendidikan

Tingkat Kerelawanan Individu

Dilihat dan dinilai berdasarkan pertanyaan kuesioner:

Tingkat saling mengenal:

$\checkmark$ Banyak anggota yang dikenal

$\checkmark \quad$ Frekuensi berinteraksi

Tingkat komitmen individu:

$\checkmark$ Alasan aktif ikut PLPBK

$\checkmark$ Frekuensi pertemuan

Sumber: Analisis Penyusun, 2014

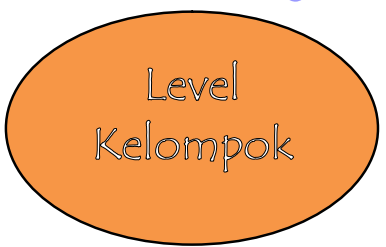

Sense of Community í

Dilihat dan dinilai berdasarkan pertanyaan kuesioner:

$\checkmark$ Tingkat kedekatan anggota dalam kelompok

$\checkmark$ Intensitas diskusi antar anggota

$\checkmark$ Tingkat ketergantungan antar anggota

$\checkmark$ Intensitas interaksi antar anggota diluar program
Tingkat Kepemimpinan,

gotongroyong, pemahaman

tuiuan, dan pembagian keria

Dilihat dan dinilai berdasarkan pertanyaan kuesioner:

Tingkat kepemimpinan:

$\checkmark$ Penilaian kepemimpinan koordinator BKM

$\checkmark$ Intensitas koordinator BKM memberikan motivasi

$\checkmark$ Tingkat kepuasan terhadap kepemimpinan koordinator

Tingkat kegotongroyongan:

$\checkmark$ Tingkat kegotongroyongan anggota BKM

Pemahaman tujuan:

$\checkmark$ Tingkat pemahaman terhadap tujuan

Pembagian kerja:

$\checkmark$ Seberapa jelas pembagian kerja yang ada 


\section{Thingegrat Realisast Program}

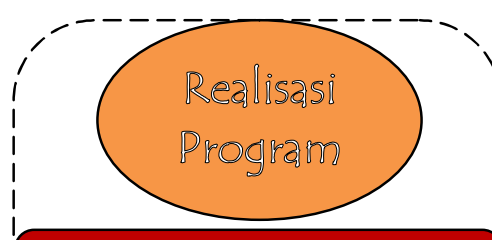

\section{Realisasi Dana, Program, Kemitraan}

Dilihat dan dinilai berdasarkan: Realisasi pemanfaatan dana BLM:

$\checkmark$ Besaran anggaran

Program pemanfaatan dana BLM:

$\checkmark$ Kesesuaian indikasi program dengan implementasi

$\checkmark$ Pertanggungjawaban dana

Besaran kemitraan program:

$\checkmark$ Jumlah dana

$\checkmark$ Sumber dana

Sumber: Analisis Penyusun, 2014

\section{GAMBAR 3}

MATRIKS PERTANYAAN KAPASITAS KELEMBAGAAN LOKAL DAN TINGKAT REALISASI PROGRAM PLPBK

\section{ANALISIS}

Pada penelitian ini pembahasan mengenai kapasitas kelembagaan lokal dan tingkat realisasi program PLPBK di Kabupaten Kendal dan Kota Pekalongan dilakukan dengan dua analisis utama, yakni analisis mengenai tingkat realisasi dan kapasitas. Dalam mengkaji tingkat realisasi program PLPBK memiliki tiga tolak ukur, antara lain realisasi pemanfaatan dana BLM, program pemanfaatan dana BLM, serta kemitraan program. Untuk analisis kapasitas kelembagaan lokal diukur dari tiga level, yakni level individu dimana melihat karakteristik dan kerelawanan individu, level kelompok untuk melihat rasa kebersamaannya, serta level organisasi untuk melihat BKM sebagai wadah dalam menjalankan PLPBK. Berikut ini adalah hasil analisis kapasitas kelembagaan lokal:

TABEL 3

KAPASITAS KELEMBAGAAN LOKAL

\begin{tabular}{llllllll}
\hline No & $\begin{array}{l}\text { Kelurahan/ } \\
\text { Desa }\end{array}$ & $\begin{array}{l}\text { Level } \\
\text { Individu }\end{array}$ & $\begin{array}{l}\text { Level } \\
\text { Kelompok }\end{array}$ & $\begin{array}{l}\text { Level } \\
\text { Organisasi }\end{array}$ & $\begin{array}{l}\text { Skor } \\
\text { Total }\end{array}$ & Kelas & Keterangan \\
\hline 1. & Kebondalem & 4,4 & 4,0 & 4,3 & 4,2 & II & $\begin{array}{l}\text { Kapasitas BKM baik } \\
\text { dalam menjalankan } \\
\text { program PLPBK }\end{array}$ \\
\hline
\end{tabular}




\begin{tabular}{llllllll}
\hline No & $\begin{array}{l}\text { Kelurahan/ } \\
\text { Desa }\end{array}$ & $\begin{array}{l}\text { Level } \\
\text { Individu }\end{array}$ & $\begin{array}{l}\text { Level } \\
\text { Kelompok }\end{array}$ & $\begin{array}{l}\text { Level } \\
\text { Organisasi }\end{array}$ & $\begin{array}{l}\text { Skor } \\
\text { Total }\end{array}$ & Kelas & Keterangan \\
\hline 2. & Podosugih & 4,025 & 3,5 & 3,9 & 3,8 & II & $\begin{array}{l}\text { Kapasitas BKM baik } \\
\text { dalam menjalankan } \\
\text { program PLPBK }\end{array}$ \\
\hline 3. & Plantaran & 3,6 & 4,1 & 4,3 & 4,0 & II & $\begin{array}{l}\text { Kapasitas BKM baik } \\
\text { dalam menjalankan } \\
\text { program PLPBK }\end{array}$ \\
\hline 4. & Kutoharjo & 4,3 & 4,3 & 4,2 & 4,3 & II & $\begin{array}{l}\text { Kapasitas BKM baik } \\
\text { dalam menjalankan } \\
\text { program PLPBK }\end{array}$ \\
\hline 5. & Sidorejo & 4,2 & 3,8 & 4,3 & 4,1 & II & $\begin{array}{l}\text { Kapasitas BKM baik } \\
\text { dalam menjalankan } \\
\text { program PLPBK }\end{array}$ \\
\hline 6. & Kramatsari & 4,7 & 4,4 & 4,3 & 4,5 & II & $\begin{array}{l}\text { Kapasitas BKM baik } \\
\text { dalam menjalankan } \\
\text { program PLPBK }\end{array}$ \\
\hline 7. & Kraton Kidul & 4,3 & 4,0 & 4,3 & 4,2 & II & $\begin{array}{l}\text { Kapasitas BKM baik } \\
\text { dalam menjalankan } \\
\text { program PLPBK }\end{array}$ \\
\hline
\end{tabular}

Sumber: Analisis Penyusun, 2014

\section{Skor tertinggi}

Skor terendah

Dari hasil skoring di atas pada level individu, kelompok, dan organisasi di tujuh kelurahan/desa yang menjalankan program PLPBK, dapat dipahami bahwa secara keseluruhan ke-tujuh BKM yang dijadikan sampel penelitian memiliki kapasitas BKM yang baik dalam menjalankan program PLPBK. Hal ini dapat dilihat dari semua BKM masuk kedalam kelas II yang berkategori baik (skor 4).

Untuk BKM yang paling baik berdasarkan hasil skoring adalah BKM di Kelurahan Kramatsari Kota Pekalongan dengan skor 4,5. Hal ini yang berarti tiap-tiap individu anggota BKM di Kelurahan Kramatsari memiliki tingkat komitmen yang tinggi, dengan rasa komunitas yang baik, serta dipimpin oleh seorang koordinator yang mampu mengkoordinir masyarakatnya dengan baik. Hal ini tentunya sangat baik untuk dapat dicontoh oleh BKM-BKM lain. Sedangkan, BKM yang memiliki skor paling rendah adalah BKM di Kelurahan Podosugih Kota Pekalongan dengan skor 3,8. Dengan demikian, perlu adanya suatu pengembangan kapasitas kelembagaan lokal seperti pendampingan BKM, pengarahan, dan komunikasi yang baik agar dapat terlaksananya kegiatan dengan baik pula. 
TABEL 4

TINGKAT REALISASI PROGRAM PLPBK

\begin{tabular}{|c|c|c|c|c|c|c|c|c|c|}
\hline No. & \multicolumn{2}{|c|}{$\begin{array}{l}\text { Pengukuran } \\
\text { Realisasi } \\
\text { Program PLPBK }\end{array}$} & $\begin{array}{l}\text { Kelurah } \\
\text { an } \\
\text { Kebonda } \\
\text { lem, Kab } \\
\text { Kendal }\end{array}$ & $\begin{array}{l}\text { Kelurah } \\
\text { an } \\
\text { Podosu } \\
\text { gih, Kota } \\
\text { Pekalon } \\
\text { gan }\end{array}$ & $\begin{array}{l}\text { Desa } \\
\text { Plantar } \\
\text { an, Kab } \\
\text { Kendal }\end{array}$ & $\begin{array}{l}\text { Desa } \\
\text { Kuto } \\
\text { harjo, } \\
\text { Kab } \\
\text { Kendal }\end{array}$ & $\begin{array}{l}\text { Desa } \\
\text { Sidore } \\
\text { jo, Kab } \\
\text { Kendal }\end{array}$ & $\begin{array}{l}\text { Kelurah } \\
\text { an } \\
\text { Kramat } \\
\text { sari, } \\
\text { Kota } \\
\text { Pekalo } \\
\text { ngan }\end{array}$ & \multirow[t]{2}{*}{$\begin{array}{l}\text { Kelurah } \\
\text { an Kraton } \\
\text { Kidul, } \\
\text { Kota } \\
\text { Pekalong } \\
\text { an } \\
82 \%\end{array}$} \\
\hline 1. & $\begin{array}{l}\text { Realisa } \\
\text { si } \\
\text { Peman } \\
\text { faatan } \\
\text { dana } \\
\text { BLM }\end{array}$ & $\begin{array}{l}\text { Besaran } \\
\text { anggar } \\
\text { an }\end{array}$ & $100 \%$ & $99 \%$ & $97 \%$ & $93 \%$ & $91 \%$ & $90 \%$ & \\
\hline \multirow[t]{2}{*}{2.} & \multirow[t]{2}{*}{$\begin{array}{l}\text { Pro } \\
\text { gram } \\
\text { peman } \\
\text { faatan } \\
\text { dana } \\
\text { BLM }\end{array}$} & $\begin{array}{l}\text { Kesesu } \\
\text { ain } \\
\text { indikasi } \\
\text { progra } \\
\mathrm{m} \\
\text { dengan } \\
\text { implem } \\
\text { entasi }\end{array}$ & Sesuai & Sesuai & Sesuai & Sesuai & Sesuai & Sesuai & Sesuai \\
\hline & & $\begin{array}{l}\text { Tingkat } \\
\text { pertang } \\
\text { gungja } \\
\text { waban }\end{array}$ & 5 & 4 & 5 & 4 & 4 & 5 & 4 \\
\hline \multirow[t]{2}{*}{3.} & \multirow{2}{*}{$\begin{array}{l}\text { Besar } \\
\text { an } \\
\text { Kemitr } \\
\text { aan } \\
\text { Pro } \\
\text { gram }\end{array}$} & $\begin{array}{l}\text { Jumlah } \\
\text { dana }\end{array}$ & $5 M$ & $1,089 \mathrm{M}$ & & $1,1 \mathrm{M}$ & 858 juta & 905 juta & 344 juta \\
\hline & & $\begin{array}{l}\text { Sumber } \\
\text { dana }\end{array}$ & $\begin{array}{l}\text { Ciptakar } \\
\text { ya, } \\
\text { Binamar } \\
\text { ga, BLH, } \\
\text { Bank } \\
\text { Jateng, } \\
\text { PSDA, } \\
\text { dan } \\
\text { kantor } \\
\text { ketahan } \\
\text { an } \\
\text { pangan }\end{array}$ & $\begin{array}{l}\text { APBD } \\
\text { tingkat I, } \\
\text { APBD } \\
\text { Kota } \\
\text { Pekalon } \\
\text { gan, } \\
\text { PDPM } \\
\text { Mandiri, } \\
\text { Pamsima } \\
\text { s, SLBM, } \\
\text { dan } \\
\text { dana } \\
\text { replikasi }\end{array}$ & & $\begin{array}{l}\text { Undip, } \\
\text { DPU } \\
\text { Cipta } \\
\text { Karya, } \\
\text { Pemkab } \\
\text { Kendal }\end{array}$ & $\begin{array}{l}\text { DPU } \\
\text { Provinsi } \\
\text { Jawa } \\
\text { Tengah }\end{array}$ & $\begin{array}{l}\text { Dindikp } \\
\text { ora, } \\
\text { DPU, } \\
\text { UPTD, } \\
\text { Menper } \\
\text { a, } \\
\text { Bapped } \\
\text { a, Bank } \\
\text { Jateng, } \\
\text { dan } \\
\text { Bank } \\
\text { Muamal } \\
\text { at }\end{array}$ & $\begin{array}{l}\text { DPU, } \\
\text { Jamsoste } \\
\text { k, } \\
\text { UNIKAL, } \\
\text { Bank } \\
\text { Muamalat } \\
\text {, toko } \\
\text { elektronk, } \\
\text { dan } \\
\text { Bappeda }\end{array}$ \\
\hline
\end{tabular}

Sumber: Hasil Analisis, 2014

\section{Keterangan:}

5: sangat baik

4: baik

3: biasa saja

2; tidak baik

1: sangat tidak baik

Pada tabel di atas, secara keseluruhan pelaksanaan program PLPBK di tujuh kelurahan/desa tersebut sudah berjalan cukup baik. Jika dilihat dari ketiga tolok ukur, Kelurahan Kebondalem Kabupaten Kendal merupakan yang paling baik dibandingkan kelurahan/desa lain. Hal ini dapat 
dilihat dari dana BLM yang telah terealisasi, program-program yang telah dilaksanakan, serta kemitraan yang telah dilakukan.

Pada pengukuran realisasi dana BLM, BKM di Kelurahan Kebondalem Kabupaten Kendal berjalan paling efektif dibandingkan dengan yang lain. Dari anggaran BLM yang telah terserap dengan baik hingga $1 \mathrm{M}$. Sedangkan, Kelurahan Kraton Kidul Kota Pekalongan anggaran BLM nya masih banyak belum terealisasi. Hal tersebut perlu adanya peninjauan program-program apa saja yang perlu dijalankan.

Untuk program pemanfaatan dana BLM, semua BKM yang menjalankan program PLPBK telah berjalan dengan baik dan sesuai dengan yang dianggarkan. Kemudian tingkat pertanggungjawaban/transparansi anggaran BLM yang telah dilakukan BKM di Kelurahan Kebondalem, Plantaran, dan Kramatsari sangat baik yang berarti anggaran yang telah dikeluarkan mampu dipertanggungjawabkan.

Kemitraan yang telah dilakukan dalam upaya penataan lingkungan permukiman telah berjalan dengan baik jika dilihat dari besaran anggaran dan pihak yang ikut membantu. Kemitraan yang paling baik dilakukan oleh BKM di Kelurahan Kebondalem Kabupaten Kendal dengan besaran anggaran $5 \mathrm{M}$. Hal ini mengindikasikan bahwa masyarakat di Kelurahan Kebondalem telah mampu mencari dana dengan baik dalam pengembangan kelurahannya. Meskipun demikian, di kelurahan/desa lainnnya pun telah mampu melakukan kemitraan dengan dana yang berbedabeda. Hal tersebut perlu dikembangkan kembali agar mampu menciptakan masyarakat yang mandiri serta berkomitmen dalam upaya peningkatan lingkungan permukimannya.

\section{KESIMPULAN}

Dilihat dari rumusan masalah berupa hanya sebagian kecil BKM yang efektif dalam menjalankan program PLPBK pada pemanfaatan program (outcomes), sebagian hanya pada tahap implementasi (output) bahkan ada beberapa yang gagal. Hal ini mengindikasikan bahwa tidak semua BKM telah siap, memiliki kapasitas, serta jiwa kerelawanan dalam perwujudan program PLPBK secara efektif. Berdasarkan hasil pengolahan data dan analisis, didapat tiga kesimpulan sebagai berikut:

1. Hasil capaian penelitian pertama yang didapat berdasarkan sasaran penelitian yakni menganalisis tingkat realisasi program PLPBK. Terdapat tiga kesimpulan, antara lain:

- Realisasi pemanfaatan dana BLM di Kabupaten Kendal dan Kota Pekalongan Realisasi pemanfaatan dana BLM yang dijalankan di tujuh kelurahan/desa di Kabupaten Kendal dan Kota Pekalongan sudah berjalan cukup efektif. BKM di Kelurahan Kebondalem Kabupaten Kendal berjalan paling efektif dibandingkan dengan yang lain. Anggaran BLM di kelurahan tersebut telah terserap dengan baik hingga 100\% dari yang dianggarkan sebesar $1 \mathrm{M}$. Sedangkan disisi lain, Kelurahan Kraton Kidul Kota Pekalongan anggaran BLM nya masih belum terealisasi sepenuhnya yakni sebesar $82 \%$.

- Program pemanfaatan dana BLM di Kabupaten Kendal dan Kota Pekalongan

Semua BKM yang menjalankan program PLPBK, yakni empat kelurahan di Kabupaten Kendal dan tiga kelurahan di Kota Pekalongan telah menjalankan programnya dengan baik sesuai dengan yang dianggarakan. Kemudian, BKM yang memiliki tingkat pertanggungjawaban/ transparansi anggaran BLM yang paling baik adalah BKM di Kelurahan Kebondalem dan Plantaran Kabupaten Kendal serta Kelurahan Kramatsari Kota Pekalongan. Ketiga BKM tersebut dianggap paling transparan dalam 
pertanggungjawaban BLM sebesar $1 \mathrm{M}$ sehingga anggaran yang telah dikeluarkan dapat berfungsi secara maksimal.

- Besaran kemitraan program di Kabupaten Kendal dan Kota Pekalongan Kemitraan yang telah dilakukan dalam upaya penataan lingkungan permukiman telah berjalan dengan baik jika dilihat dari besaran anggaran dan pihak yang ikut membantu. Kemitraan yang paling baik dilakukan oleh BKM di Kelurahan Kebondalem Kabupaten Kendal dengan besaran anggaran mencapai $5 \mathrm{M}$. Hal ini mengindikasikan bahwa masyarakat di Kelurahan Kebondalem telah mampu mencari dana dengan baik dalam pengembangan kelurahannya. Meskipun demikian, di kelurahan/desa lainnnya pun telah mampu melakukan kemitraan dengan dana yang berbeda-beda. Untuk sumber dana kemitraan di tujuh kelurahan/desa yang menjalankan program PLPBK ini juga cukup bervariatif, diantaranya Ciptakarya, Binamarga, BLH, PSDA, Bank, hingga Universitas.

2. Hasil capaian penelitian kedua yang didapat berdasarkan sasaran penelitian yakni menganalisis kapasitas kelembagaan lokal pada tiga level, yakni level individu, kelompok, dan organisasi. Terdapat empat kesimpulan, antara lain:

- Kapasitas kelembagaan lokal di Kabupaten Kendal dan Kota Pekalongan

Dari hasil skoring pada level individu, kelompok, dan organisasi di tujuh kelurahan/desa yang menjadi sampel penelitian dapat dipahami bahwa secara keseluruhan memiliki kapasitas BKM yang baik dalam menjalankan program PLPBK. Hal ini dapat dilihat dari semua BKM masuk kedalam kelas II yang berkategori baik (skor 4). Untuk BKM yang paling baik adalah BKM di Kelurahan Kramatsari Kota Pekalongan dengan skor 4,5. Sedangkan, BKM yang memiliki skor paling rendah adalah BKM di Kelurahan Podosugih Kota Pekalongan dengan skor 3,8.

- Kapasitas kelembagaan lokal dilihat dari level individu Untuk BKM yang memiliki skor tertinggi adalah Kelurahan Kramatsari Kota Pekalongan dengan skor 5 (sangat baik) yang berarti anggota BKM tersebut memiliki tingkat saling mengenal dan komitmen yang sangat baik dalam menjalankan program PLPBK. Namun, untuk Desa Plantaran Kabupaten Kendal memiliki skor terendah yakni 3,8.

- Kapasitas kelembagaan lokal dilihat dari level kelompok

Hasil skoring menunjukkan secara keseluruhan dari empat variabel tersebut, baik BKM di Kabupaten Kendal maupun BKM di Kota Pekalongan memiliki skor 4 yang berarti baik. Untuk skor tertinggi pada level kelompok yang berarti rasa kebersamaan ialah BKM di Kelurahan Kramatsari Kota Pekalongan dengan skor 4.4, sedangkan skor terendah dalam rasa kebersamaan di dalam satu kelompok adalah Kelurahan Podosugih Kota Pekalongan dengan skor 3,5.

- Kapasitas kelembagaan lokal dilihat dari level organisasi Untuk BKM yang memiliki skor tertinggi terdapat 5 BKM, antara lain BKM di Kelurahan Kebondalem, Plantaran, Sidorejo, Kramatasari, dan Kraton Kidul. Sedangkan, BKM yang memiliki skor terendah adalah BKM Podosugih. Meskipun demikian, baik BKM di Kabupaten Kendal maupun di Kota Pekalongan memiliki skor 4 atau kapasitas BKM pada level organisasi bernilai baik. Hal ini menunjukkan bahwa secara keseluruhan BKM yang menjadi 10 BKM terbaik dalam menjalankan program PLPBK di Jawa Tengah memang memiliki kapasitas yang baik pula dalam menjalankan program-programnya.

3. Research question terjawab dari hasil analisis kapasitas kelembagaan lokal dan tingkat realisasi PLPBK. Artinya secara ilmiah telah dapat dibuktikan bahwa kapasitas BKM di empat kelurahan di Kabupaten Kendal dan tiga kelurahan di Kota Pekalongan berbeda- 
beda dalam upaya pelaksanaan program PLPBK secara efektif dalam penataan kawasan lingkungan permukiman di perkotaan.

\section{DAFTAR PUSTAKA}

Bossert dan Mitchel. 2010. "Health sector decentralization and local decision-making: Decision space, institutional capacities and accountability in Pakistan" dalam Jurnal Social Science and Medicine.

Departemen Pekerjaan Umum, Direktorat Jenderal Cipta Karya. 2009. Pedoman Pelaksanaan PNPM Mandiri Perkotaan.

Dunn, William N. 1998. Pengantar Analisis Kebijakan Publik. Yogyakarta: Gajahmada University Press.

Fultanegara, Anggun A. 2013. Kapasitas Kelembagaan Lokal dan Efektivitas Program Penataan Lingkungan Permukiman Berbasis Komunitas. Tugas Akhir Tidak Diterbitkan, Jurusan Perencanaan Wilayah dan Kota, Fakultas Teknik, Universitas Diponegoro, Semarang.

Hughey, Joseph et al. 1999. "Sense of Community in Community Organizations: Strucuture and Evidence of Validity" dalam Journal of Community Psychology. Vol. 27 No. 1, pp. 97-113.

Inam, Aseem. 2002. Institutional Analysis and Urban Planning: Means Or Ends? Urban And Regional Research Collaborative: Working Paper Series. University of Michigan.

Kapucu, et al. 2011. "Survival of the fittest: Capacity Building for Small Nonprofit Organization". Evaluation and Program Planning, Vol. 34, pp. 236-245.

Kementerian Komunikasi dan Informatika RI, Direktorat Jenderal Informasi dan Komunikasi Publik. 2011. Program Penanggulangan Kemiskinan Kabinet Indonesia Bersatu II.

Manaf, Asnawi. 2012. "Lembaga Keswadayaan Masyarakat Lokal dan Perannya di Dalam Mendukung Pelaksanaan Program Nasional Pemberdayaan Masyarakat", dalam Prosiding Seminar Nasional Green Urban Housing Policy. Semarang: Biro Penerbit Planologi UNDIP.

Mehring, et al. 2011. "Local institutions: Regulation and valuation of forest use-Evidence from Central Sulawesi, Indonesia” dalam Jurnal Land Use Policy.

Sakip, Siti Rasidah Md et al. 2012. "Sense of Community in Gated and Non-Gated Residential Neighborhoods" dalam Procedia: Social and Behavioural Science. Vol. 50, pp. 818-826.

Uphoff, Norman. 1986. Local Institutional Development: Analytical Sourcebook with Cases. West Hartford: Kumarian Press. 